\title{
The political economy of Israel's 'social justice' protests: a class and generational analysis
}

\author{
Zeev Rosenhek $^{\mathrm{a} *}$ and Michael Shalev ${ }^{\mathrm{b}}$ \\ ${ }^{a}$ Sociology, Political Science and Communication, Open University of Israel, Raanana, Israel; ${ }^{b}$ Sociology, \\ Hebrew University, Jerusalem, Israel
}

(Received 24 September 2013; accepted 30 September 2013)

\begin{abstract}
In the summer of 2011, similar to and partly inspired by Spain's 15M (indignados) movement, Israel experienced an unprecedented wave of socio-economic protest featuring tent encampments and mass rallies. Headlined 'the people demand social justice', the protest was surprising since distributive conflicts and social policy issues are peripheral to Israeli politics, and Israel was not in the throes of an economic crisis. These were not anti-austerity protests, but reflected the eroding life chances of young adults. Specifically, liberalisation of Israel's political economy - which contributed to a substantial rise in the living standards of the parental generation of the middle class and improved their life chances in the 1990s - is now impeding inter-generational class reproduction for their children. We document significant changes in home ownership, relative incomes, and the value of higher education and other assets that were previously the key to middle class incomes and lifestyles. The impact of neo-liberal policies is evident, for instance, in the declining scope and generosity of the public sector's role in employment and housing. At the subjective level, on the eve of the protests young adults with higher education were less optimistic about their economic prospects than other groups. Finally, even though the protests appeared to be broadly consensual and inclusive, a closer look reveals that its core supporters and activists were drawn from social and political sectors closely associated with the middle class.
\end{abstract}

Keywords: protests; class reproduction; class-generational units; Israel

Similarly to other phenomena that are understood as global, the wave of mass protests in 2011 in many advanced capitalist societies has exhibited a combination of common supra-national features and idiosyncratic local traits (Pabst, 2011). The protest movements that emerged in Europe and North America have a number of characteristics in common: the initiators and leaders of these movements are educated young people with middle class backgrounds, protesting against their own reduced economic opportunities and the widening inequality between the wealthy and the rest of the population; their protests express deep alienation from institutionalised politics; they occupy public space in an attempt to imbue it with new meaning and instill alternative forms of political action; they hold mass demonstrations attended by broader audiences; and they make diffuse demands on the state for more or less radical changes to the economy and socioeconomic policies - demands that are fundamentally redistributive (Tejerina \& Perugorria, 2012). The movements in different countries also share specific practices of protest and collective action: the wide use of theatrical performativity; a reliance on digital technologies and new media to

*Corresponding author. Email: zeevro@openu.ac.il 
spread their message and mobilise activists; a network logic of action and organisation; and an effort to implement direct democracy and non-hierarchical coordination (Bennett \& Segerberg, 2012; Castells, 2012; Mason, 2012).

These features were shared by the protests that unexpectedly broke out in Israel in the summer of 2011 under the banner 'the people demand social justice', and succeeded in dominating the public agenda for two tumultuous months. The global wave of protests doubtless expanded the structure of political opportunities for the Israeli movement by offering models for imitation and ideational frameworks for identification and legitimation. Similarly to the Spanish, Greek, Portuguese and Chilean cases, the Israeli protest successfully garnered support from far beyond the internal nucleus of activists, mobilising mass rallies with often unprecedented numbers of supporters who had not previously participated in this kind of protest activity over economic and social issues. Yet the protests in Israel emerged in unusual circumstances. As we show below, economic conditions differed profoundly from those that struck such a blow to Western Europe and the USA following the financial crisis that erupted in 2008. Furthermore, the legacy of protest politics in Israel - and politics in general - also differed from those in most established democracies. Since 1967, if not before, they have been dominated by Israel's protracted conflict with Arab states and the Palestinians, and by the future of the Occupied Territories - issues that are related to conflicts over competing definitions of collective identity in Israeli society. Distributive conflicts and issues have been marginalised and have failed to serve as a platform for mass political mobilisation.

Our objective in this article is to examine the relations between the underlying economic and political factors that led to the surprising emergence of Israel's social protest. To this end we shall offer a class and generational analysis that focuses on the protest's instigators and leaders - young adults from the middle class - examining changes in their life chances and their relationship to the dynamics of Israel's political economy. Our argument is that political-economic dynamics in Israel (and perhaps in other countries as well) have created a situation in which this class-generational unit is struggling to maintain the lifestyle and living standards enjoyed by the previous generation of the middle class and to which they grew accustomed during the formative years when they lived in their parents' home. The comprehensive liberalisation of Israel's political economy in recent decades - which contributed to a substantial rise in the living standards of the parental generation and improved their life chances in the 1990s - is now impeding inter-generational class reproduction for a significant segment of the middle class, leading to growing discontent based on relative deprivation (Runciman, 1966; Wolbring, Keuschnigg, \& Negele, 2013). Together with political dynamics, we argue, this class-generational dynamic is foundational to the growth of the protest movement and its broad demands for 'social justice'.

The relevance of this analysis goes beyond the Israeli case, and it can shed light on one of the key theoretical questions posed to the study of social movements by the current wave of protests in western societies. While in a number of important ways Occupy-type protests have followed a pattern familiar from earlier 'new' and 'post-materialist' social movements, the socio-economic injustice frames animating these protests and their central demands are unmistakably materialistic. They seek to alter the distribution of resources and the structure of inequality, and they challenge key elements of the prevailing model of state-economy relations. In a dialectical process, the class and generational dynamic that has accompanied the institutionalisation of the neoliberal regime and its crisis led to the emergence of a protest movement that seeks to repoliticise distributive and economic issues.

\section{The empirical puzzle - a thoroughly unexpected protest}

The Israeli protests began in the wake of Internet campaigns by disgruntled consumers during the first half of 2011 (Alimi, 2012; Grinberg, 2013; Monterescu \& Shaindlinger, 2013). The opening 
step was an encampment in the heart of the Tel Aviv financial district, inspired by the Spanish model, which was designed to draw attention to the housing problems faced by young students. ${ }^{1}$ Enthusiastically publicised by most of the mainstream media as well as via social media and other informal channels, the protest quickly expanded in three directions: establishment of parallel tent camps in other locations around the country; support by and collaboration with diverse cause groups and lobbying groups, most importantly the national union of students; and a series of half a dozen mass rallies that peaked on September 3 with an unprecedented turnout of 300,000 in Tel Aviv and 100,00 in other areas of the country. Both the demands and the collective identity adopted by the protest broadened as it developed, from an initial emphasis on housing and other consumer issues to a redefinition as a middle class protest with aspirations to represent 'the people' in a struggle for 'social justice'. In addition to students and young people, the protest leaders embraced other publics including striking medical residents and parents complaining about the cost of childcare, and made efforts to reach out to marginalised groups, primarily Jewish residents of poor neighborhoods and the geographical periphery.

In retrospect, it is tempting to see the Israeli protest as the inevitable consequence of more than two decades of radical neoliberal policies that undermined the economic and social security of large segments of the Israeli population. But at the time, the remarkable success of the movement in mobilising wide public support took all observers of Israeli society and politics utterly by surprise. It was hard to believe that 400,000 Israelis would take to the streets over issues such as the distribution of wealth in society, and social and economic policy. First, as noted, the protest in Israel emerged in entirely different economic circumstances from those prevalent in the USA and much of Europe. The protests there were the result of a deep and ongoing economic crisis that hit a large part of the population extremely hard, including the middle class, and particularly its younger generation. Unemployment soared, reaching $10 \%$ in the USA and the Eurozone in 2010 , and $20 \%$ in Spain. Unemployment among the young was, and remains, especially high - $18 \%$ in the USA; $21 \%$ in the Eurozone; and $41 \%$ in Spain in $2010 .^{2}$ Moreover, in countries where the financial crisis turned into a public debt crisis, states adopted austerity policies that involved deep cutbacks in public expenditure, which seriously harmed both social rights and the employment opportunities of young adults from the middle class. Given that those states were simultaneously channeling trillions of taxpayers' dollars into failing banks and financial institutions, one of the central motifs of the protests was that massive public resources were being diverted to save the very financial capitalists and their lackeys who had caused the crisis, while as a consequence, the remainder of the population was obliged to suffer contraction of the welfare state.

In Israel, by contrast, on the eve of the protests the global crisis had not significantly harmed domestic economic performance. The financial market remained relatively stable, no bailouts and massive monetary injection were necessary and there was no real threat of a debt crisis. From the second half of 2009 Israel enjoyed favorable growth rates by international standards, and unemployment declined in 2010 to less than 7\% (twice that among the young), one of the lowest levels experienced since 1985. Furthermore, in 2010 and 2011 no severe cutbacks to public budgets were on the agenda. Nevertheless, as we explain below, these aggregate indicators conceal a far more complex socio-economic reality characterised not only by ever-widening gaps in the distribution of economic resources, but also by relative deterioration in the economic opportunities of the younger generation as a whole, and that of the middle class in particular. Be that as it may, in the summer of 2011 Israel was exempt from either the socio-economic distress or the atmosphere of a deep crisis demanding radical change in the political economy which were the basis for the protest movements in other countries.

The Israeli protest was also surprising because of the striking contrast it posed to the cleavages and identities that had characterised the political field and contentious mobilisation in Israel since 
1967. These were all primarily organised around issues of war and peace, including relations with the Palestinians and the region's Arab states, and the future of the Occupied Territories. These issues had been central in both institutional and non-institutional politics, and had largely defined the socio-political identities of different groups, voting patterns, and the demands of most of the country's protest movements. The main extra-parliamentary movements that had successfully positioned themselves at the top of the political agenda and were responsible for the largest mass mobilisations emerged around these issues, such as the opposing movements regarding the future of the Occupied Territories (Peace Now and Gush Emunim), and those targeted to support of or opposition to either ceding territory for peace (first with Egypt, later with the Palestinians) or controversial actions by the Israeli military (Hermann, 2009). Additional political conflicts that sometimes occupied the center of the public stage - and especially the conflict between Israel's religious and secular populations - were closely related to competing views concerning war and peace issues and to the wider political question of the ethno-national definition of the Israeli state and society. Consequently, the main political conflicts in Israel were perceived and interpreted as enacting a fundamental struggle between contradictory political and cultural collective identities. While the 1970s and 1980s saw instances of protest over issues of distribution, they reached nothing like the scale of mass mobilisation seen in the protest of 2011 (Lehman-Wilzig, 1990). A partial exception was a protest in 1971 led by young residents of slum neighborhoods who styled themselves as Israeli Black Panthers. Though the protest spread throughout the country, it did not reach massive dimensions and continued to be viewed as the particularistic outcry of the second generation of disadvantaged Jewish immigrants from Arab countries (Bernstein, 1984).

Given this type of politics, in which social conflicts were understood and formulated in terms of clashes between fundamental cultural identities, distributive issues and class interests played a marginal role in electoral politics, serving as only a muted or implicit political cleavage. Even when the material interests of different groups formed the basis for their organisation and political action, they were understood and portrayed in terms of cultural identities - mainly religious and/ or ethnic - or in terms of an effort at attaining peace and democratisation (Filc, 2006; Peled, 1998; Shalev \& Levy, 2005). Although public support for the welfare state and expressions of concern about the increasing economic inequality were more pronounced in Israel than in most other countries (Shalev, 2007), until the summer of 2011 those issues did not produce large protest movements or mass political mobilisation, and they were certainly not the grounds for the construction of socio-political identities.

The third factor that should have narrowed the structure of political opportunities for the emergence of a mass social protest in Israel is related to the rise in recent decades of alienation and mistrust toward politics and politicians, often described as anti-politics (Arian \& Shamir, 2005; Hermann, 2012a). It would seem that most Israelis became indifferent, antithetical even, to politics (Filc, 2012). This atmosphere of anti-politics was felt not only in declining turnouts at election time, but also in what would seem to be a reduced propensity to take part in protest activities (Yishai, 2012). In the context of the accelerated liberalisation of Israel's political economy and the penetration of individualistic and consumerist principles into many spheres of life, the neoliberal project of depoliticising economic policy, and indeed economics in general, and its definition as the preserve of 'apolitical' experts, was remarkably successful in Israel (Maman \& Rosenhek, 2011).

It appeared that most Israelis, especially among the middle class, were not at all interested in taking part in collective action with political objectives, particularly when those objectives were related to the politics of the distribution of resources. Moreover, rising apathy toward and revulsion from politics were viewed as particularly notable among the younger members of the middle class - a generation that was portrayed in public discourse as hedonistic, radically individualistic, 
and indifferent to matters of public import, particularly those of a socio-economic nature. However, it was precisely this class-generational unit that launched and led a protest that raised the banner of solidarity and social justice.

Before presenting our explanation for the surprising emergence of Israel's social protest, we shall position it within the broader context of the theoretical challenges posed by the current wave of protests in advanced capitalist countries to the study of social movements, and especially to the new social movements approach.

\section{The theoretical puzzle - new social movements and the current wave of protests}

For three decades sociologists have been discussing the 'death of class' and its decline as an organising principle for the articulation of interests, identities, and collective action (Pakulski $\&$ Waters, 1996). Their discussions have raised questions about the relevance of material life chances, class identities, distributive demands, and socio-economic issues in general for collective action in both institutionalised and non-institutionalised politics (Clark \& Lipset, 2001; Evans, 1999). Scholars have highlighted the increasing importance of post-materialist socio-cultural issues and conflicts as the primary bases for political mobilisation at the expense of the class identities and distributive demands that used to play such an important role in the political dynamics of capitalist societies until the final quarter of the twentieth century (Kitschelt, 1994). According to this approach, political struggles in contemporary societies are more likely to form around questions of values and lifestyle than around the unequal distribution of economic resources. The conceptualisation of post-industrial societies as founded on post-materialist identities and values (Inglehart, 1990) is also embodied in the 'new social movements' paradigm, which has dominated the study of social movements for decades (Larana, Johnston, \& Gusfield, 1994).

This approach sharply distinguished between the classic protest movements of advanced capitalist societies and those that emerged since the student movement of the 1960s. These distinctions referred to the collective grievances and identities constructed and expressed by the movements, as well as to features of their activists and supporters and the political practices they used. The classic protest movements were strongly related to identities formed in the economic arena; they expressed material concerns and interests; put forward distributive demands; were led or supported by the organised working class; and deployed highly institutionalised practices, usually linked to hierarchically organised labor unions or left-wing parties (Piven \& Cloward, 1977). The new social movements, by contrast, emerged tightly associated with identities that were formulated on the basis of cultural distinctions and lifestyle, and their demands were mainly related to post-materialist values and the recognition of those distinct identities (Kriesi, Koopmans, Duyvendak, \& Giugni, 1995; Steinmetz, 1994). Even when some of the issues dealt with by certain of these movements had a clearly distributive aspect, their demands were primarily framed in terms of the recognition of the distinct culturally based identities of excluded and oppressed groups. Some of the more notable examples of these new social movements are the women's movements, student movements, the gay rights movement, the movements against nuclear arms and energy, and the environmental movement. The main support base of these movements is the educated middle and upper-middle classes, especially their younger members. They are also characterised by a principled rejection of institutionalised politics and by practices that aim to underscore this rejection: fluid and seemingly non-hierarchical organisational structures; participatory democracy and deliberative decision making; and creative and innovative protest activities in which humor, playfulness, and theatrical performativeness play a central part (for the Israeli case, see Katriel \& Livio, 2012; Larana et al., 1994). 
The recent wave of protest in advanced capitalist societies - from the Portuguese Geração à Rasca ('desperate generation') and Indignados in Spain, through the Occupy Wall Street movement in the USA to the social justice movement in Israel - poses a serious challenge to the dichotomous distinction between old materialistic social movements and new post-materialistic ones. On the one hand, the current wave of protest shares many characteristics with the new social movements: the instigators, leaders, and many of the supporters are youngsters with a middle class background, and they are generally university students or graduates. Moreover, following consolidation of these practices by the preceding anti-globalisation movement, the contemporary protests have further developed the fluid and participatory internal practices and forms of protest characteristic of new social movements. At the same time, however, the recent protest wave took shape around opposition to existing modes of resource distribution and demands for alternative socio-economic policies. Finally, in the process of repoliticising socio-economic issues, these movements have attempted to construct new collective identities based on quasi-class distinctions. While there is no longer talk of 'the working class' or 'the labor movement', these new identities are nonetheless constructed and formulated in relation to the structure of social inequality: 'the $99 \%$ vs. the $1 \%$ ' in the USA; 'the people against bankers and politicians' in Spain; and 'the middle class versus the tycoons' in Israel. In this regard, the current protests rearticulate the relationship between identities and distributive conflicts as the basis for political action. Our analysis of the Israeli case suggests that the class dimension of the protests can be sharpened and clarified by focusing on the links between generational and class dynamics and their association to changes in the political economy.

\section{Generational and class dynamics and the social protest in Israel}

Building on the classic theory of 'sociological generations' laid out by Karl Mannheim (1952), we propose to examine the material origins of the social protest in Israel through the concept of 'class-generational unit'. Mannheim saw generation and class as two distinct categories that indicate different types of social location. A similar assumption underlies most contemporary analyses of political action in general, and protest activities in particular, which tend to focus on either class or age as the basis for the formation of social movements (see, for instance, Whittier, 1997). In contrast, our argument is that the intersection of class and generational locations may define a distinct social position that can serve as basis for collective political action, particularly when the process of inter-generational class reproduction is disrupted and it ceases to operate smoothly.

We define a class-generational unit as a set of individuals with shared formative experiences in the areas of consumption and life chances, experiences that derive primarily from their parents' class location. These experiences influence their economic outlook and expectations regarding their adult lives. This conceptualisation is anchored in a Weberian understanding of class, that is, one that focuses on individuals' positions in different markets, primarily the labor market, but also the housing market, and which assumes that these are the main fields in which the life chances of individuals and families are determined. Accordingly, the middle class is defined in terms of the economic, social, and cultural resources that enable integration in the labor market in positions that, in principle, ensure economic stability and levels of income that allow relatively high levels of consumption, including home ownership. In modern societies academic education has served as the central mechanism of social closure critical to enabling members of the middle class to attain advantageous jobs, as well as a form of cultural capital that marks and sharpens their privileged position and facilitates inter-generational class reproduction (Bourdieu, 1984). In the case of young adults, academic education is seen in society as the most important condition conducive to entry into the middle class, and it functions as an important factor shaping young adults' 
expectations regarding life chances, prestige, and other privileges. Accordingly, empirically we treat income and higher education as indicative of actual (or for young people, potential) membership in the middle class.

As we have already suggested, in generational terms the leaders of the 2011 protest were the children of the liberalisation of Israel's political economy. They grew up in middle and uppermiddle class families in the 1990s and the early 2000s just as most members of those classes were enjoying a significant improvement in their standard of living and were adopting modes of conspicuous consumption that were quite novel in Israel. Their parents were the main beneficiaries of the liberalisation of the Israeli economy, and this shaped their experiences as a classgenerational unit. However, when reaching early adulthood, they found themselves in a situation where the successful reproduction of their parents' life chances was in no way guaranteed, including the level and modes of consumption to which they had become accustomed during their formative years. As we explain below, the same features of the liberalised political economy that had formed the basis for their parents' significantly improved life chances since the 1990s, had become a hindrance to many of the younger generation seeking to reproduce their class position. In other words, many of the sons and daughters of the beneficiaries of the neoliberal regime became its losers.

Before examining the relationships between class-generational dynamics and changes in Israel's political economy, we shall present some figures that point to the diminished life chances of the younger middle class generation in the last decade that have contributed to the emergence and strengthening of a sense of relative deprivation. This erosion is documented by means of both objective indicators (home ownership and attainment of superior incomes) and individuals' subjective perception of their economic situation and prospects. The empirical data presented here, like our overall analysis, refer only to Israel's Jewish majority. While Palestinian-Arab citizens (one-fifth of the total Israeli citizenry) supported the objective of reducing inequality and rehabilitating the welfare state, they appear to have viewed the protest (quite accurately) as an internal Jewish matter, and their active participation was far more limited than among the Jewish population (Hermann, 2012b). Furthermore, because of the specific location of Palestinian citizens in Israel's political economy, its internal class-generational dynamics differ from those of the Jewish population. Their housing problems were quite different to those of Jews, and a growing segment of the younger generation succeeded in achieving inter-generational upward mobility by academic education or entrepreneurial initiative (Haidar, 2013).

Two other sectors of Israeli society - immigrants from the Former Soviet Union and Haredim (ultra-orthodox Jews) - are also either treated separately, or excluded from our analysis. Young Haredi families are a special case because of widespread poverty, the result of a combination of high fertility and low labor force participation (many male spouses are engaged in full-time religious studies). The younger members of the massive wave of 'Russian' immigration to Israel that began after 1989 are exceptional in having achieved high levels of upward mobility, in part because early arrivals were seriously disadvantaged. Finally, available data do not permit drawing a distinction between young Jewish adults of Ashkenazi (European) and Mizrahi (Middle Eastern) origins, since there is no information on their grandparents' country of birth. Still, there are indications that the classic ethnic divide among Israeli Jews is less relevant today than in the past in influencing the chances of young adults to enter the middle class. In this regard, recent research by Momi Dahan (2013) suggests that Israeli-born Mizrahim now enjoy the same weight in the Israeli middle class as they do in the population as a whole.

The protest was sparked by demands regarding the difficulties faced by young adults especially those living in the Tel Aviv area - in attaining affordable housing. Even when the movement and its demands were broadened to include other issues, and more general critiques of inequality and neoliberal policy were articulated, the issue of the younger generation's 
limited access to housing continued to play a central role in the protests. Analysis of large-scale annual surveys carried out by the Israeli Central Bureau of Statistics (CBS) shows that in the course of the 2000s there was a decline in the rate of home ownership among young families. However, as detailed in Table 1, the decline occurred mainly among young Israeli-born Jews, especially those living in the central area of the country. Both Russian-speaking immigrants living outside of the Center and Haredim (ultra-orthodox Jews) also experienced falling rates of ownership, but they were much more moderate. Russian-speaking immigrants in the center of the country actually improved their rates of ownership, though they still trailed behind other groups, while among Arabs in Israel, home ownership was and is almost universal.

This raises the question of whether the decline in home ownership among the young Israeliborn Jewish population was particularly prominent among the middle class. This is addressed by distinguishing between different quintiles of household income. ${ }^{3}$ Figure 1 shows that the decline in the probability that a young family owns the home in which they live has mainly affected the middle quintile and above, while we find the steepest decline (17 percentage points) in the highest

Table 1. Home ownership among young working families by sector and period.

\begin{tabular}{lcc}
\hline & 2001-2004 (\%) & 2009-2010 (\%) \\
\hline Israeli-born Jews - Center & 74 & 60 \\
Israeli-born Jews - Other areas & 73 & 63 \\
Russian-speaking immigrants - Center & 37 & 47 \\
Russian-speaking immigrants - Other areas & 65 & 61 \\
Haredim (all areas) & 73 & 68 \\
Arabs (all areas) & 90 & 93 \\
Total - Center & 69 & 61 \\
Total - Other areas & 76 & 71 \\
\hline
\end{tabular}

Source: Authors' analysis of CBS Income Surveys. 'Center' refers to Tel Aviv and surrounding areas.

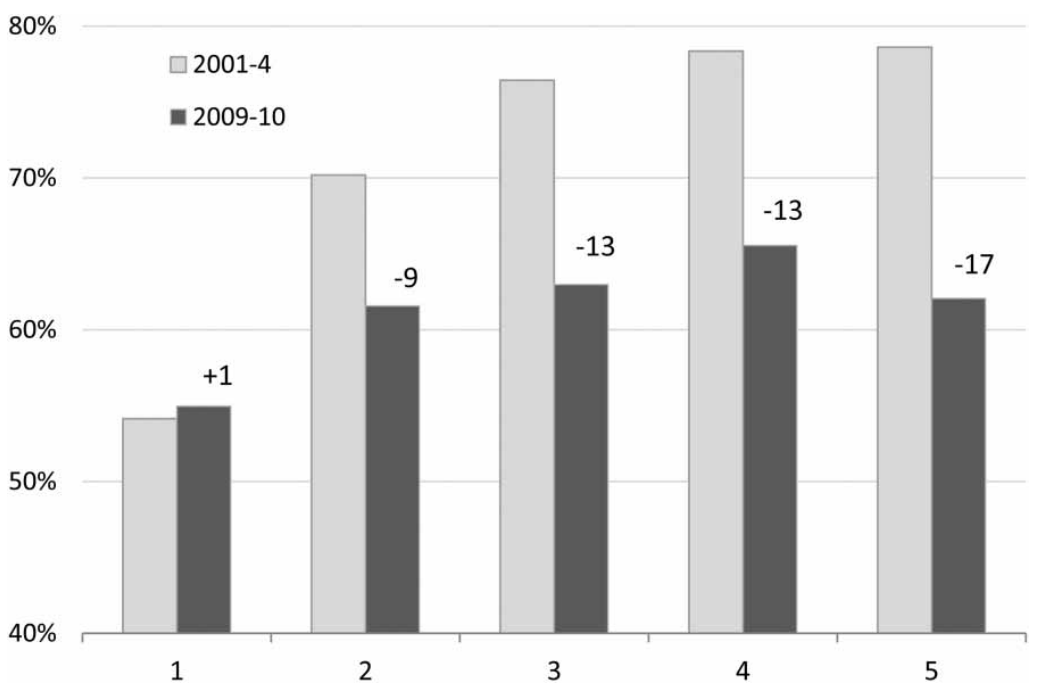

Figure 1. Rate of home ownership among young working families (Israeli-born Jews) by income quintile and period.

Source: See Table 1. 
Table 2. Percentage of Israeli-born Jewish families in the upper income quintile by age and education of household head.

\begin{tabular}{cccccc}
\hline & \multicolumn{2}{c}{ University graduates } & & \multicolumn{2}{c}{ Others } \\
\cline { 2 - 3 } \cline { 5 - 6 } & Ages 30-39 (\%) & Ages 40-49 (\%) & & Ages 30-39 (\%) & Ages 40-49 (\%) \\
\hline $2000-2004$ & 49 & 54 & & 12 & 16 \\
$2009-2010$ & 40 & 54 & & 8 & 16 \\
\hline
\end{tabular}

Source: Adapted from Shalev (2012, Fig. 12a).

quintile. We suspect that this is partly the result of exceptionally large increases in property prices at the high end of the market, and partly because lifestyle changes have led some privileged young families to delay buying a permanent home, possibly while purchasing another property as an investment or an option for the future. In any case, the data available to us do not contradict the protesters' argument that it has become harder for young adults from the middle class to buy an apartment.

The position occupied by the young individuals and families in the national hierarchies of earnings and income has deteriorated markedly over the last decade (Shalev, 2012). A salient indicator for our argument regarding shrinking access of young families to middle class lifestyles is the proportion of these families that succeed in attaining relatively high incomes. Table 2 shows shifts between the beginning and end of the decade preceding the protests in the percentage of families reaching the highest quintile of household income. The figures refer only to Israeliborn Jews and they are split by both age and education. Among families in which the head of the household ${ }^{4}$ had an academic degree and was in his or her thirties, the proportion in the upper quintile declined from $49 \%$ in $2000-2004$ to $40 \%$ in $2009-2010$. In contrast, the other groups experienced little or no decline.

The evidence presented so far clearly suggests that the structure of opportunities facing the younger generation of Israeli-born Jews has contracted in recent years, in both labor and housing markets, and that this reduction has been especially felt among those with a university education. However, when examining processes of political mobilisation it is no less important - and perhaps even more so - to look at the way in which individuals perceive their economic situation. To shed light on this, we draw on the CBS annual Social Survey to evaluate changes in perceptions between 2006 and 2010 while distinguishing between four groups within the Jewish population defined by age (25-34 and 35-44) and whether or not they have academic education. It is worth noting that for the Jewish population as a whole, evaluations of personal economic circumstances in 2010 - the year before the protest erupted - were very positive, more so than in 2006. For instance, the proportion of respondents who expected their economic situation to improve in the future rose from $42 \%$ in 2006 to $47 \%$ in 2010 , and the proportion of those satisfied with their current economic situation rose from $55 \%$ to $61 \%$ over the same period. Quite surprisingly, a similar pattern pertains in relation to housing, where the proportion of those satisfied rose from $83 \%$ in 2006 to $87 \%$ in 2010 .

However, the picture becomes especially interesting when we compare rates of change between different segments of the population. The pattern that emerges is that the trend among university-educated young adults differed from that of the three other groups - young adults without an academic education and the two groups of older adults. This pattern can be clearly seen in Figure 2, which shows the relative change between the two points in time in relation to respondents' perception of their present economic situation. The only group with an increase (of 14\%) in the proportion expressing dissatisfaction was that of the younger and university- 


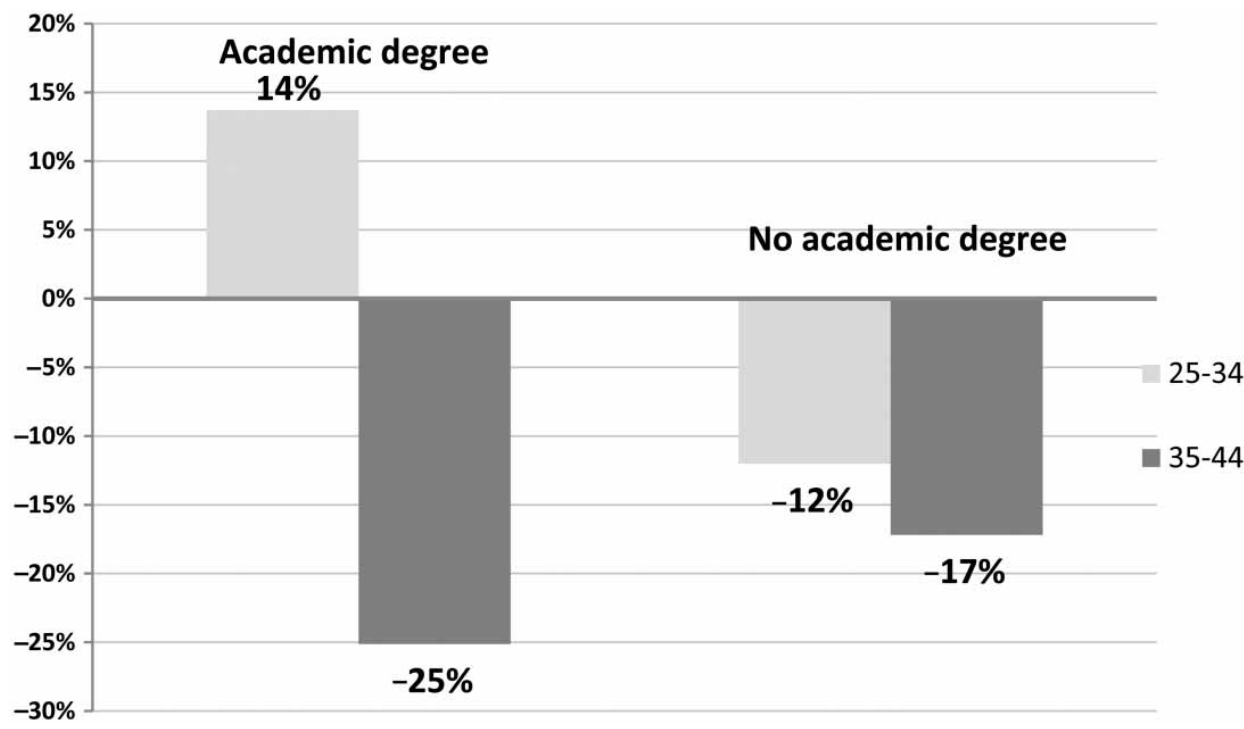

Figure 2. Percentage change between 2006 and 2010 in the proportion of respondents dissatisfied with their personal economic situation by education and age.

Source: Authors' analysis of CBS Social Survey 2006 and 2010.

educated Israelis, while the other three groups saw a significant decline. Similar trends emerged in responses to a question regarding concern about losing one's job. Younger and university-educated respondents were the only group in which the percentage saying they were not at all worried fell.

Table 3 presents a parallel analysis of a question asking about satisfaction with housing. Once more, the trend among the young and highly educated differed from that of the other groups. While among the older respondents and those without an academic education there was a notable decline in levels of dissatisfaction with housing, there was no change among the university-educated and younger respondents. This implies that, relative to the other groups, their perceived situation regarding housing had deteriorated. The same trends were identified in relation to respondents' satisfaction with their income.

To summarise, in the course of the last decade both the objective and perceived economic situation of young Jewish adults with an academic education (not including immigrants) suffered significant deterioration, leading to a growing sense of relative deprivation. These trends were reinforced as a basis for political mobilisation by the formative experiences of that class-generational unit as children of Israel's liberalisation, who grew up with a significant improvement in their families' standard of living. In the section that follows, we contend that the declining

Table 3. Percentage change between 2006 and 2010 in the proportion of respondents dissatisfied with their housing situation by education and age.

Percentage change

25-34: Academic degree

35-44: Academic degree 0

25-34: No academic degree

$-37$

35-44: No academic degree

$-22$

$-15$

Source: Authors' analysis of CBS Social Survey 2006 and 2010. 
ability of young middle class Israelis to reproduce their parents' life chances is inextricably related to the shift in relations between state and the economy in Israel.

\section{Class-generational dynamics and Israel's political economy}

Nearly four decades ago Henry Rosenfeld and Shulamit Carmi published a path-breaking analysis of the mechanisms through which the state created Israel's middle class during the first decades of its existence (Rosenfeld \& Carmi, 1976). The Israeli developmental state produced a broad structure of opportunities for the veteran Ashkenazi population in both labor and housing markets, which enabled this group to accumulate significant amounts of financial and social capital. The establishment of a wide-ranging bureaucratic and professional state apparatus; the construction of public and private industrial sectors; the expansion of the banking system - all these gave this relatively privileged segment of society the opportunity to assume advantageous positions in the primary labor market and to advance down the path of resource accumulation. Heavily state-subsidised public housing programs - usually in collaboration with the Histadrut (peak labor organisation) and targeted at veteran residents - were a further mechanism for producing the middle class in the 1950s and 1960s (Rosenhek, 2007). Ownership of these housing assets - which was concentrated in the center of the country and whose value rose continuously was critical to the inter-generational transfer of wealth and the reproduction of the class structure in Israel (Lewin-Epstein \& Semyonov, 2000).

The process by which the middle class gained advantages deepened in the subsequent second generation of Israelis born in the 1940s and 1950s. This generation inherited considerable economic, social, political, and cultural capital from its predecessor and continued to benefit from preferential economic resources provided by the state. It profited from the expansion of the welfare state, which reached its peak in the 1970s, and a significant part of which was designed to assist the middle class. It was this class-generational unit that benefited from the first wave of the expansion of higher education in Israel in the 1970s, enabling its members to acquire academic degrees that were extremely valuable in the labor market almost without cost. It was also the primary beneficiary of very generous state subsidies for home purchase through entitlement-based mortgage programs that operated from the early 1970s to the early 1990s (Rosenhek, 2007).

Later on, upon reaching middle age in the 1980s and 1990s, the second generation of the middle class accumulated the economic, social, and cultural resources that enabled it to nurture a degree of autonomy from the state, thereby becoming an important supporter of the liberalisation of the Israeli political economy that was taking place at the time. This trend was given clear political expression in the support of the veteran middle and upper-middle class for the Oslo process, which combined decolonisation with liberalisation of the political economy and Israel's integration into the global economy (Shafir \& Peled, 2002). Although the Oslo "peace process' was a resounding failure, the liberalisation of the political economy has only deepened since 2000 (Maman \& Rosenhek, 2012). This shift led to far-reaching changes in the structure of inequality in Israel, including the formation of a new class of capitalists with a controlling position in the Israeli economy, enormous widening of gaps in income and wealth, a decline in economic and social security among large parts of the lower middle class, and the marginalisation of disadvantaged groups (Kristal, 2013). As part of these changes, significant sections of the second generation of the veteran middle class managed to leverage the economic and social resources that they had inherited and accumulated to benefit from the new political-economic regime.

The neoliberal turn of the Israeli political economy contributed to expanding the opportunities of many members of this class-generational unit, improving their life chances both in labor and consumer markets. First, the expansion of the private sector brought about by privatisation and foreign investment provided them with opportunities to exploit their social and cultural capital 
in order to attain high-ranking professional and managerial positions. The proliferation of lawyers, accountants, and various types of consultants offering services to the business sector attested to this process. Enhanced integration of the local economy in the global economy including the liberalisation of international trade and the growth of the high-tech industry opened up new pathways for entrepreneurs and intermediaries between the local economy and global markets. In addition, financial liberalisation and the resulting explosive growth of the financial sector not only produced well-paid and attractive jobs, but in some periods also substantial capital gains for investors. Those who remained employed in the public sector managed to exploit existing institutional arrangements and their positions of power in order to preserve the advantages of the sheltered labor market in which they were employed. Processes such as the privatisation of public corporations (including in the arms industry) and outsourcing were typically implemented in ways that preserved existing privileges, and the sting of many neoliberal reforms in the public labor market was deferred in practice to future generations of employees.

These developments contributed to a significant rise in the relative income levels of those with advantageous jobs. One indication of this trend is that the share of the top two deciles in the overall gross income of salaried workers climbed from $39.3 \%$ in 1988 to $44.9 \%$ in 2009 (Swirski \& Konor-Attias, 2007, p. 7; Swirski, Konor-Attias, \& Abu-Khala, 2010, p. 13). At the same time, neoliberal tax reforms implemented since the early 2000s significantly reduced income tax levels for high earners, adding to their disposal income. It is fair to say that capitalism's ideological promise that each generation, at least those from the middle class, would have better life chances than their predecessors was realised in the case of the second generation of Israel's middle and upper-middle classes. In contrast, for many members of the third generation this is no longer the case. This turnaround is primarily due to the effects of liberalisation on young newcomers.

Current aspirants to middle class life chances and lifestyle enter a labor market bereft of many of the protections that used to be afforded to workers. The labor conditions, salaries, and employment security of young workers in a large swathe of the contemporary labor market - including many professionals - are far worse than they used to be, prior to processes of neoliberal 'flexibilisation' (Paz-Fuchs, 2009). Irregular forms of employment through manpower agencies or subcontractors that first appeared in non-professional fields have been spreading to several professions commonly taken up by young people with higher education, particularly women and especially in the public sector. Similar to what occurred in other countries, these processes have created a new precariat composed of educated young people from middle-class backgrounds (Standing, 2011).

The life chances of those young adults were also undermined by welfare state reforms. While the most drastic cutbacks, mainly since 2003, were made to programs that targeted the lower classes - such as unemployment insurance, guaranteed minimum income, and child benefits the Israeli welfare state also contracted in areas that are important to the middle class. Reduced public spending on education and health and the heavy cost of childcare and quasi-private education for young children hurt young middle class families, who today have to pay for services that their parents were given for free, or at least were heavily subsidised. The drastic reduction in state support for the middle class in the realm of housing is particularly notable. During the 1990 s, mortgage schemes for young couples that included a significant state subsidy that primarily benefited the middle class were almost entirely eliminated. In parallel, the difficulty of buying a home increased as a result of large price rises in real terms. Those who managed to buy a property had to make far higher mortgage repayments than their parents had in the 1970s when they bought their first apartment with substantial governmental subsidies.

To summarise this section, the generational dynamics of the economic situation of the Israeli middle class explain the unease which was at the root of the unexpected emergence of a mass 
protest movement around distributive issues and material interests. The children of Israel's liberalisation found themselves in a situation where capitalism's promise of a constantly improving standard of living failed to be met. In light of what appears to be a failure in the inter-generational reproduction of the life chances of a sizable segment of the middle class, this class-generational unit sought to position itself at the forefront of a broad movement issuing wide-ranging distributive demands in the name of 'the people'. As we shall see in the following section, the protest movement embodied an effort to rearticulate material interests and demands while coping with divisions and conflicts formulated in terms of cultural identities - that is, to maneuver between a politics of redistribution and a politics of recognition.

\section{Status politics and republicanism}

So far we have focused our analysis on class-generational dynamics and their relation to the political economy, while emphasising what was novel about the protest as a mass mobilisation that emerged around distributive issues. However, this is not to say that the social protest of 2011 was detached from the principles that have organised the political field in Israel for the past four decades: political identities based on cultural distinctions and conflicts over non-economic issues. The complex relationship between the protest and pre-existing identities and conflicts in Israeli society was central to the public debate that emerged around it: the conflict between left and right (as they are defined in Israel), between the secular and the ultra-Orthodox, between the Ashkenazi (European origin) center and the Mizrahi (Middle Eastern origin) periphery, between rich and spoiled Tel Aviv and the rest of the country - all these conflicts and their associated identities were both simultaneously present in and absent from the protest and the discourse surrounding it.

At the most overt level, the protest made broad and inclusive demands on the state. Alongside the demand to improve the life chances of the middle class, and especially its younger generation, demands were also made that the state aid the disadvantaged and ease their plight by expanding social protection. The combination of a wide range of specific demands with the all-inclusive demand for social justice and solidarity and the attribution of responsibility to the state for its citizens' welfare, created the impression that the protest movement was actually demanding the rebuilding of a universal welfare state that would advance a more egalitarian distribution of resources. Leaders of the protest movement apparently hoped that these demands would construct a 'pan-Israeli' socio-political identity that would rise above the old familiar political and cultural conflicts and identities, especially those related to the future of the Occupied Territories and secular-religious relations. The aim was to create an inclusive identity representing the general social interest, which would rise above the old divisions and quarrels - in the face of corrupt politicians, of governments, past and present, which abrogated responsibility for their citizens, and 'tycoons' who were exploiting the people.

To be sure, in terms of public support and participation in mass demonstrations, the protest was remarkably successful in transcending entrenched social and cultural boundaries. For example, according to the 'Peace Index' survey carried out by the Israel Democracy Institute a few weeks after the protests began, $88 \%$ of all respondents said they were either very or quite supportive (Hermann, 2011). While launched by young, educated, left-wing and secular Tel Avivians, the protest was embraced by diverse segments of the population whom the former tried to construct as 'the Israelis'. In this regard, the Israeli protests were similar to the preceding $15 \mathrm{M}$ movement in Spain, where tent encampments in the main squares sparked mass demonstrations throughout the country with participants who were more diverse in terms of both generation and class. 
However, if we look below the surface, it turns out that the protest was deeply embedded in the same identities and conflicts that have structured politics in Israel since the 1970s. Public support varied significantly between different sections of the Jewish population, mirroring the classic divisions of Israeli society and politics. Left-leaning Israelis supported and participated in the protest more than those on the right; the secular more than the religious; the educated more than the less educated; and middle to high-earners more than low-earners (Hermann, 2012b). These differences in support and participation reflect the tension between the effort to construct the protest as expressing the interests of all Israelis, and its class-related socio-political foundations. The core of the protest remained largely the domain of the secular, educated and 'left wing' middle class.

The tension between inclusiveness and privilege was also expressed in the republican motifs mobilised in the protests, which have always been a central basis for claims-making in Israeli politics (Shafir \& Peled, 2002). The protesters' demands were often justified in relation to the contribution of the middle class to society, in terms of both military service and its contribution to the economy. In this way, protest leaders sought to constitute a collective socio-political identity which represented the middle class as a 'universal class', expressing and advancing the common good. The centrality of this motif was clearly manifested in the results of the 2013 elections, particularly in the remarkable success of the newly established party 'There is a future' (Yesh Atid), which won 19 seats in the Parliament (out of 120) and became the second largest party after the Likud. Established and led by Yair Lapid, a TV celebrity-turned-politician, the party capitalised on the protests and built its electoral campaign on the grievances and claims of the secular middle-class. It presented itself as the true and only representative of this 'universal class' - defined as those who contribute to the country by working, paying taxes and serving in the military but are neglected by the state, as opposed to those who gain resources without contributing, especially the Ultra-Orthodox population.

In more general terms, the call for social justice can be interpreted as an attempt by the middle class, including the parental generation, to reposition itself at the center of the political and social fields as the backbone of society. During the 1990s, the middle class in Israel had attempted to construct itself as a universal class that promoted the common good through the peace project. However, after the collapse of the Oslo process and in a political context in which a discourse based on peace-making was no longer accepted as representing the common good, but rather the opposite, the middle class turned instead to distributive issues and social justice, not only in order to improve its life chances but also in order to regain recognition and socio-political dominance. This aspiration was reinforced by the persistent political dominance of a coalition of the nationalist right wing and ultra-orthodox parties. Members of the secular middle class felt that they had been pushed to the margins by these dominant forces, which were orchestrating a full-frontal assault on the values and practices of liberal democracy. In response, the protest movement was also a way to rebuild the collective identity of the secular and 'left wing' middle class. Mass demonstrations were an opportunity for this group to take to the streets and celebrate solidarity, after a long absence from the public sphere as a collective. The protest thus not only embodied a politics of distribution, which formed its overt outer layer, but also an implicit inner layer driven by a politics of status and recognition managed by a social sector that sought to reclaim its dominance through a revised collective identity.

What emerges, therefore, is an interesting reversal in the relationship between material interests and socio-cultural identities. Israeli politics has long blurred material interests and class categories as bases for political action, and demands on the state have been couched in terms of the recognition of distinct social-cultural identities and amelioration of status inequalities. The protest of 2011 rearticulated the relations between these two dimensions. Its demands were explicitly formulated in distributive terms as opposition to economic inequality and to the state's withdrawal 
from responsibility for the welfare of its citizens. The protestors and their supporters portrayed their action as a new politics that would replace the old, Balkanized struggles between culturally defined 'sectors'. However, while the protest was undoubtedly innovative in comparison to traditional Israeli politics, this does not imply that the politics of status simply vanished; rather, it changed its location. The group which had insistently disowned the strategy of political mobilisation on the basis of an explicit 'sectoral' identity, implicitly did precisely that in the backstage of the protests.

\section{Conclusions}

Israel's 'social justice' movement was even more encompassing than the mass protests that preceded it in Spain, Portugal, and Greece. Yet it was an improbable candidate for such inclusivity, given that the Israeli movement had to contend with deeply institutionalised socio-political cleavages and lacked the unifying and motivating stimulus of radical state-imposed austerity. We have argued that the material foundation of the Israeli protest was embedded in a generational shift in the life chances of the middle class, shaped by Israel's transition to a neoliberal political-economic regime.

The institutionalisation of the neoliberal model in Israel in the early 2000s undermined the promise of inter-generational reproduction of middle class life chances for significant numbers of the younger generation of that class. However, alongside this class-generational dynamic, the protest was also closely linked to pre-existing social and cultural identities and the conflicts between them. In this sense, the subtext of the protest can be interpreted as a bid by the secular and 'left wing' middle class to reclaim its social dominance by reinventing itself as a universal class under the flag of inclusiveness and social justice. The tension between the material and cultural interests of the protest's instigators and their attempt to build an inclusive identity that would rise above societal cleavages and conflicts percolated through many aspects of the protest. In this regard, it remained deeply embedded in the distinguishing features of the Israeli political field for the last 40 years.

We opened this article by referring to other protest movements that emerged in advanced capitalist countries following the deep economic crisis that started in 2008 , but with only cursory reference to the causal role of this protest wave for the Israeli case. Occupy-type protests in western countries and preceding popular uprisings in some Arab states certainly played a part in the Israeli protest, despite sharp differences in political and economic circumstances. Similar to other global phenomena, there were processes of diffusion through which ideas and practices crossed national boundaries. The global wave of protests in 2010 and 2011 expanded the structure of political opportunities for the protest in Israel by providing models for imitation and ideational frameworks for identification and legitimation.

That said, this article aims to contribute in a different way to our understanding of the 'networks of outrage and hope' (Castells, 2012) which emerged in Israel and other advanced capitalist societies, by focusing on domestic conditions. We believe that the class and generational analysis presented here for the Israeli case may be relevant to other recent protest movements as well, despite clear differences in specific circumstances (Mason, 2012). For the first time since World War II in Europe and North America, and since 1948 in Israel, it is far from clear that young adults from middle class backgrounds will enjoy a higher standard of living than their parents, or even succeed in maintaining the conditions that they grew up with. For many young adults, capitalism's basic promise to the middle class regarding the uninterrupted inter-generational reproduction of life chances and improvement in living standards has been broken. The global financial crisis has accentuated this turnaround in the hardest-hit countries, but it has not been solely responsible for it. Like the crisis itself, the threat facing young would-be managers, 
professionals, and entrepreneurs anticipating advantageous positions in labor and consumer markets fundamentally results from the uneven and contradictory effects of the neoliberal model of economic growth and the diminished role that it assigns to the state as an employer, regulator, and provider of social protection. The consequent economic threat to young people, which is new and unexpected for those who entered adulthood with middle-class advantages, explains the emergence of protest movements which on the one hand resemble the 'new' social movements of old, but on the other raise demands for redistribution and seek to construct identities based on quasi-class membership and economic inequality.

The most important outcome of this wave of contention - an outcome which the Israeli case shares with others - is the repoliticisation of economic issues in general, and socio-economic policy in particular. One of the most notable successes of the neoliberal project in recent decades was its depoliticisation of the economic sphere (Hay, 2007; Maman \& Rosenhek, 2011). According to the ideology that rationalised this development, distributive processes should be determined by market forces and economic policy should be made primarily by experts. Very little political space was left between 'apolitical' market forces and 'apolitical' experts. The protests in advanced capitalist societies, including Israel, have sought to reopen this space. They succeeded for a time in bringing politics back into the economy, and the economy back into politics - but it is still too early to say whether this shift will contribute to significant changes in the political economy, or else will turn out to have been only a passing episode.

\section{Notes}

1. See activism.org.il, especially a post on 7 July 2011 under the pseudonym 'Amnon Hagibor'. The official protest website is j14.org.il.

2. Employment and Labour Markets: Key Tables from OECD (http://www.oecd-ilibrary.org/employment/ employment-and-labour-markets-key-tables-from-oecd 20752342).

3. In both Figure 1 and Table 2 income has been adjusted for household size using the OECD equivalence scale.

4. Among married couples with children - our unit of analysis - the CBS normally defines the household head as the spouse with higher earnings.

\section{Notes on contributors}

Zeev Rosenhek is Associate Professor and Chair of the Department of Sociology, Political Science and Communication at the Open University of Israel. His fields of interest include state-economy relations, institutional change and the political economy of neo-liberalization. He is currently conducting research on the ways in which central banks have diagnosed and explained the current global crisis and their effects on institutional change.

Michael Shalev is Professor of Sociology and Political Science at the Hebrew University of Jerusalem. He is currently Visiting Professor at the University of the Basque Country, conducting research comparing the social politics of mass mobilisation and consensus formation in the Spanish and Israeli protest movements of 2011. He has published on the comparative political economy of the advanced OECD countries and the politics and political economy of Israel.

\section{References}

Alimi, E. Y. (2012). 'Occupy Israel': A tale of startling success and hopeful failure. Social Movement Studies, 11(3-4), 402-407.

Arian, A., \& Shamir, M. (2005). On mistaking a dominant party in a dealigning system. In A. Arian \& M. Shamir (Eds.), The elections in Israel, 2003 (pp. 13-31). New Brunswick: Transaction Publishers. 
Bennett, W. L., \& Segerberg, A. (2012). The logic of connective action. Information, Communication \& Society, 15, 739-768.

Bernstein, D. (1984). Conflict and protest in Israeli society: The case of the Black Panthers of Israel. Youth and Society, 16, 129-152.

Bourdieu, P. (1984). Distinction: A social critique of the judgement of taste. Cambridge MA: Harvard University Press.

Castells, M. (2012). Networks of outrage and hope: Social movements in the internet age. Cambridge, UK: Polity.

Clark, T. N., \& Lipset, S. M. (2001). The breakdown of class politics: A debate on post-industrial stratification. Baltimore: Johns Hopkins University Press.

Dahan, M. (2013). Did the melting pot succeed in the economic field? Working paper, Federman School of Public Policy, The Hebrew University of Jerusalem (in Hebrew).

Evans, G. (Ed.). (1999). The end of class politics? Class voting in comparative context. Oxford: Oxford University Press.

Filc, D. (2006). Populism and hegemony in Israel. Tel-Aviv: Resling Publishing (in Hebrew).

Filc, D. (2012). Neo-Liberalism, sovereignty, and the crisis of representation in Israel. In T. Hermann (Ed.), By the people, for the people, without the people? The emergence of (Anti)political sentiment in western democracies and in Israel (pp. 226-246). Jerusalem: The Israel Democracy Institute.

Grinberg, L. L. (2013). The J14 resistance mo(ve)ment: The Israeli mix of Tahrir and Puerta Del Sol. Current Sociology, 61, 491-509.

Haidar, A. (2013). 'The emergence of an Arab middle-class in Israel', Opening plenary on Social Classes in Israel. Paper presented at the 44th Annual Meeting of the Israeli Sociological Society, Ruppin Academic Center.

Hay, C. (2007). Why we hate politics. Cambridge: Polity Press.

Hermann, T. (2009). The Israeli peace movement: A shattered dream. Cambridge: Cambridge University Press.

Hermann, T. (2011). The Israeli democracy index, 2011. Jerusalem: The Israel Democracy Institute (in Hebrew).

Hermann, T. (2012a). Introduction. In T. Hermann (Ed.), By the people, for the people, without the people? The emergence of (Anti)political sentiment in western democracies and in Israel (pp. 9-39). Jerusalem: The Israel Democracy Institute.

Hermann, T. (2012b). The Israeli democracy index, 2012. Jerusalem: The Israel Democracy Institute (in Hebrew).

Inglehart, R. (1990). Culture shift in advanced industrial society. Princeton: Princeton University Press.

Katriel, T., \& Livio, O. (2012). The poetics of language and space in the Israeli 2011 protest. Paper presented at the Annual Conference of the Association of Social Anthropologists of the UK and the Commonwealth, Jawaharlal Nehru University, New Delhi, India.

Kitschelt, H. (1994). The transformation of European social democracy. Cambridge: Cambridge University Press.

Kriesi, H., Koopmans, R., Duyvendak, J. W., \& Giugni, M. G. (1995). New social movements in Western Europe: A comparative analysis. Minneapolis: University of Minnesota Press.

Kristal, T. (2013). Slicing the pie: State policy, class organization, class integration, and Labor's share of Israeli national income. Social Problems, 60, 100-127.

Larana, E., Johnston, H., \& Gusfield, J. R. (1994). New social movements: From ideology to identity. Philadelphia: Temple University Press.

Lehman-Wilzig, S. N. (1990). Stiff-necked people, bottle-necked system: The evolution and roots of Israeli public protest, 1949-1986. Bloomington: Indiana University Press.

Lewin-Epstein, N., \& Semyonov, M. (2000). Migration, ethnicity, and inequality: Homeownership in Israel. Social Problems, 47, 425-444.

Maman, D., \& Rosenhek, Z. (2011). The Israeli central bank: Political economy, global logics and local actors. London: Routledge.

Maman, D., \& Rosenhek, Z. (2012). The institutional dynamics of a developmental state: Change and continuity in state-economy relations in Israel. Studies in Comparative International Development, $47,342-363$.

Mannheim, K. (1952). The problem of generations. In K. Mannheim (Ed.), Essays on the sociology of knowledge (pp. 276-322). London: Routledge and Kegan Paul.

Mason, P. (2012). Why it's kicking off everywhere: The new global revolutions. London: Verso. 
Monterescu, D., \& Shaindlinger, N. (2013). Situational radicalism: The Israeli 'Arab Spring' and the (un) making of the rebel city. Constellations, 22(2), 1-24.

Pabst, A. (2011). The resurgence of the civic. Possible futures. Retrieved from http://www.possible-futures. org/2011/11/29/the-resurgence-of-the-civic/

Pakulski, J., \& Waters, M. (1996). The death of class. London: Sage.

Paz-Fuchs, A. (2009). Objectionable work in Israel. Comparative Labor Law and Policy Journal, 31, 471-486.

Peled, Y. (1998). Towards a redefinition of Jewish nationalism in Israel? The enigma of Shas. Ethnic and Racial Studies, 21, 703-727.

Piven, F., \& Cloward, R. (1977). Poor people's movements: Why they succeed, how they fail. New York: Pantheon.

Rosenfeld, H., \& Carmi, S. (1976). The privatization of public means, the state-made middle class, and the realization of family value in Israel. In J. Peristiany (Ed.), Kinship and modernization in Meditarranean society (pp. 131-159). Rome: Center for Mediterranean Studies.

Rosenhek, Z. (2007). Inclusionary and exclusionary dynamics in the Israeli welfare state: State building and political economy. In H. Herzog, T. Kochavi \& S. Selniker (Eds.), Generations, locations, identities: Contemporary perspectives on society and culture in Israel (pp. 317-349). Jerusalem: The Van-Leer Jerusalem Institute and Hakibbutz Hameuchad Publishing House (in Hebrew).

Runciman, W. G. (1966). Relative deprivation and social justice: A study of attitudes to social inequality in twentieth-century England. Berkeley CA: University of California Press.

Shafir, G., \& Peled, Y. (2002). Being Israeli - The dynamics of multiple citizenship. Cambridge: Cambridge University Press.

Shalev, M. (2007). The welfare state consensus in Israel: Placing class politics in context. In S. Mau \& B. Veghte (Eds.), Social justice, legitimacy and the welfare state (pp. 193-213). Aldershot: Ashgate.

Shalev, M. (2012). The economic background of the social protest of summer 2011. In D. Ben-David (Ed.), State of the nation report: Society, economy and policy in Israel 2011-2012 (pp. 161-220). Jerusalem: Taub Center for Social Policy Studies in Israel.

Shalev, M., \& Levy, G. (2005). The winners and losers of 2003: Ideology, social structure and political change. In A. Arian \& M. Shamir (Eds.), The elections in Israel - 2003 (pp. 212-232). Brunswick, NJ: Transaction Books.

Standing, G. (2011). The Precariat - The new dangerous class. London: Bloomsbury Academic.

Steinmetz, G. (1994). Regulation theory, post-Marxism, and the new social movements. Comparative Studies in Society and History, 36, 176-212.

Swirski, S., \& Konor-Attias, E. (2007). Workers, employers and the distribution of Israel's national incomeLabor report: 2006. Tel-Aviv: Adva.

Swirski, S., Konor-Attias, E., \& Abu-Khala, H. (2010). Workers, Employers and the distribution of Israel's national income - Labor report: 2009. Tel-Aviv: Adva Center (in Hebrew).

Tejerina, B., \& Perugorria, I. (Eds.). (2012). From social to political: New forms of mobilization and democratization, conference proceedings. Bilbao: Universidad del Pais Vasco.

Whittier, N. (1997). Political generations, micro-cohorts, and the transformation of social movements. American Sociological Review, 62, 760-778.

Wolbring, T., Keuschnigg, M., \& Negele, E. (2013). Needs, comparisons, and adaptation: The importance of relative income for life satisfaction. European Sociological Review, 29, 86-104.

Yishai, Y. (2012). Escape from politics: The case of Israel. In T. Hermann (Ed.), By the people, for the people, without the people? The emergence of (Anti)political sentiment in western democracies and in Israel (pp. 288-313). Jerusalem: The Israel Democracy Institute. 